\title{
Kualitas Fermentasi Silase Ransum Komplit Berbasis Hasil Samping Jagung, Sawit dan Ubi Kayu
}

\section{Fermentation Quality of Complete Feed Silage Based on Corn, Palm and Cassava by Products}

\author{
Lendrawati, Nahrowi, dan M. Ridla
}

Fakultas Peternakan Universitas Andalas

Kampus Unand Limau Manis Padang, 25163

e-mail: len1303@yahoo.com

(Diterima: 12 Mei 2011; Disetujui: 1 Oktober 2011)

\begin{abstract}
The study was conducted to evaluate fermentation quality of complete feed silage based on corn, palm and cassava by products. Each complete feed was ensiled separately in 50 litres silo and were opened 6 weeks after ensiling. The silage products were evaluated in terms of physical (colour, smell, and presence of moulds), chemical (pH, N-amonia content, WSC loss and dry matter loss) and microbial properties (number of lactic acid bacteria). The data was analyzed by using Completely Randomized Design with three treatments and six replications, followed by LSD test. The result showed that all complete feed silage treatments were having good quality. Fermentation quality of silage was affected with kind of complete feed silage $(P<0.05)$. In general, all of treatments had good fermentation quality of silage, because it have lower pH, ammonia content, WSC loss and dry matter also. It is concluded that quality fermentation of complete feed silage based on corn, palm and cassava by products had good quality and can be recomended as ruminant feeding.
\end{abstract}

\section{Keywords: completed feed silage, quality fermentation}

\section{PENDAHULUAN}

Ketersediaan pakan masih menjadi kendala pengembangan ternak ruminansia di Indonesia. Hal ini disebabkan sebagian besar bahan pakan bersifat musiman, terkonsentrasi di suatu wilayah dan tidak tepatnya manajemen pengelolaan pakan yang diterapkan selama ini. Faktor lainnya adalah semakin sempitnya lahan penanaman hijauan pakan karena dialih fungsikan menjadi kawasan pemukiman dan industri. Akibatnya kualitas dan harga pakan menjadi fluktuatif, selanjutnya mempengaruhi produktivitas ternak. Sehingga diperlukan suatu teknologi peyiapan pakan yang tidak hanya tahan simpan, tapi juga mengandung nutrien yang sesuai dengan kebutuhan ternak. Salah satunya adalah teknik silase ransum komplit dengan memanfaatkan sumber pakan lokal.

Berbeda dengan silase berbahan baku tunggal seperti silase rumput atau jerami jagung, silase ransum komplit mempunyai beberapa keuntungan diantaranya: 1) tersedianya substrat yang mendukung terjadinya fermentasi yang baik, sehingga mempunyai tingkat kegagalan yang jauh lebih rendah jika dibandingkan dengan silase berbahan tunggal. 2) mengandung nutrien yang sesuai dengan kebutuhan ternak. Hasil samping tanaman jagung dan ubi kayu serta pengolahan sawit merupakan sumber bahan baku pakan lokal yang cukup tersedia sepanjang tahun. Sistem pengolahan bahan baku di atas selama ini melalui teknik pengeringan yang sangat tergantung dengan musim, sehingga kurang tepat untuk dikembangkan.

Kajian terdahulu mengenai pemberian $100 \%$ silase ransum komplit berbasis sampah organik tidak menunjukkan adanya gangguan pencernaan dan fungsi metabolisme pada sapi perah (Ramli et al., 2006). Sementara pemanfaatan hasil samping jagung, sawit dan ubi kayu dalam bentuk silase ransum komplit selama ini belum pernah dilaporkan. Berdasarkan pemikiran 
di atas, maka dilakukan penelitian untuk mengkaji kualitas fermentasi dan nutrisi silase ransum komplit berbasis hasil samping jagung, sawit dan ubi kayu.

\section{METODE}

Penelitian ini dilaksanakan dari bulan Januari sampai Juni 2008 di Laboratorium Ilmu dan Teknologi Pakan, Laboratorium Ilmu Nutrisi Ternak Perah Fakultas Peternakan IPB. Bahan utama penelitian ini adalah hasil samping sawit (daun, lumpur, serat buah dan bungkil inti sawit), jagung (jerami, kulit, tongkol dan jagung giling) dan ubi kayu (daun, kulit dan onggok). Bahan tambahan lain terdiri dari rumput gajah, bungkil kelapa, dedak padi, molases, urea dan premiks. Alat yang digunakan dalam penelitian adalah chopper, timbangan, silo, kandang metabolik dan peralatan laboratorium lainnya. Ransum perlakuan disusun berdasarkan kebutuhan ternak domba masa pertumbuhan yaitu dengan kandungan protein kasar $12,81 \%$ dan TDN 67\% (NRC 1985).

Silase ransum komplit berbasis hasil samping jagung (SRKJ), silase ransum komplit berbasis sawit (SRKS), dan silase ransum komplit berbasis ubi kayu (SRKU) dibuat sesuai formulasi dan terdiri atas enam ulangan pada setiap perlakuan. Sumber hijauan (rumput gajah, jerami jagung, kulit jagung, tongkol jagung, daun kelapa sawit, daun dan kulit ubi kayu) pada masing-masing perlakuan terlebih dahulu dipotong $3-5 \mathrm{~cm}$ dengan menggunakan chopper. Kemudian dilayukan selama 12 jam (satu malam) pada ruang terbuka. Masing-masing hijauan tersebut selanjutnya dicampur dan diaduk sampai merata dengan sumber konsentrat (dedak padi, bungkil kelapa, jagung, onggok, bungkil inti sawit, molases, urea dan premiks) sesuai dengan perlakuannya. Komposisi kimia ransum komplit masing-masing perlakuan disajikan pada Tabel 1. Hasil campuran ransum tersebut dimasukkan ke dalam silo (tong plastik volume 50 liter), dipadatkan, ditutup rapat dan diinkubasi dalam kondisi anaerob selama enam minggu. Sampel silase dari masing-masing perlakuan diambil untuk analisa kualitas fermentasi dan nutrisi di laboratorium.

Peubah yang diamati dalam penelitian ini adalah kualitas fermentasi ditentukan berupa karakteristik fisik, kimia dan mikrobial. Karakteristik fisik (melalui pengamatan) meliputi warna, bau dan keberadaan jamur dengan cara memisahkan dan menimbang produk silase yang terkontaminasi jamur pada permukaan silo. Karakteristik kimia; pengukuran $\mathrm{pH}$ menggunakan $\mathrm{pH}$ meter, bahan kering melalui analisa proksimat (AOAC 1999), N$\mathrm{NH}_{3}$ metode difusi Conway (1957), total gula dari Water Soluble Carbohydrate (WSC) berdasarkan Dubois et al. (1956).

Tabel 1. Komposisi kimia ransum komplit masing-masing perlakuan

\begin{tabular}{lccc}
\hline $\begin{array}{c}\text { Komposisi kimia ransum } \\
\text { komplit (\%BK) }\end{array}$ & $\begin{array}{c}\text { Basis Jagung } \\
\text { (SRKJ) }\end{array}$ & $\begin{array}{c}\text { Basis Sawit } \\
\text { (SRKS) }\end{array}$ & $\begin{array}{c}\text { Basis Ubi Kayu } \\
\text { (SRKU) }\end{array}$ \\
\hline Protein kasar & 12,81 & 12,81 & 12,82 \\
Lemak kasar & 6,38 & 10,53 & 6,96 \\
Serat kasar & 19,68 & 26,10 & 17,78 \\
Abu & 7,79 & 10,88 & 9,89 \\
BETN & 55,74 & 42,72 & 59,90 \\
TDN & 67,00 & 67,00 & 67,24 \\
Kalsium & 0,293 & 0,302 & 0,327 \\
Pospor & 0,549 & 0,602 & 0,553 \\
\hline
\end{tabular}


Karakteristik kimia; pengukuran $\mathrm{pH}$ menggunakan $\mathrm{pH}$ meter, bahan kering melalui analisa proksimat (AOAC 1999), N$\mathrm{NH}_{3}$ metode difusi Conway (1957), total gula dari Water Soluble Carbohydrate (WSC) berdasarkan Dubois et al. (1956). Sementara karakteristik mikrobial silase dilakukan dengan cara penghitungan jumlah koloni bakteri asam laktat pada media MRS agar berdasarkan metode Total Plate Count (TPC) menurut Fardiaz (1992). Rancangan percobaan yang digunakan adalah Rancangan Acak Lengkap dengan 3 perlakuan (SRKJ, SRKS dan SRKU) dengan 6 kali ulangan. Data yang diperoleh dianalisis ragam dengan software SPSS versi 15 .

\section{HASIL DAN PEMBAHASAN}

\section{Karakteristik Fisik Silase Ransum Komplit}

Hasil pengamatan silase ransum komplit berbasis hasil samping jagung, sawit dan ubi kayu setelah 6 minggu ensilase menunjukkan warna yang tidak jauh berbeda dari sebelum ensilase yaitu campuran hijau, kuning dan coklat (Tabel 2). Campuran ketiga warna ini merupakan pengaruh keanekaragaman bahan yang digunakan pada pembuatan silase seperti; rumput gajah, daun ubi kayu, daun kelapa sawit, jerami jagung, serat buah sawit, kulit ubi kayu, dedak padi, bungkil kelapa dan lumpur sawit. Hal ini sesuai dengan yang direkomendasikan Macaulay (2004) bahwa silase yang berkualitas baik ditunjukkan dengan warna hijau terang sampai kuning atau hijau kecoklatan tergantung materi silase.

Semua perlakuan silase ransum komplit setelah 6 minggu ensilase menunjukkan bau khas fermentasi asam laktat. Hal ini didukung oleh pernyataan Saun dan Heinrichs (2008) bahwa silase yang baik akan mempunyai bau seperti susu fermentasi karena mengandung asam laktat, bukan bau yang menyengat.
Keberadaan jamur pada permukaan silo ditemukan pada perlakuan SRKJ dan SRKS sebesar 7,64 dan 3,83\%. Sementara perlakuan SRKU tidak terkontaminasi jamur. Persentase jamur yang didapatkan pada penelitian ini lebih rendah dari pernyataan Davies (2007) bahwa keberadaan jamur pada produk silase sekitar $10 \%$.

\section{Karakteristik Kimia dan Mikrobial Silase Ransum Komplit}

pH. Hasil penelitian menunjukkan bahwa $\mathrm{pH}$ ransum komplit berbasis hasil samping jagung, sawit dan ubi kayu setelah 6 minggu ensilase adalah 3,80, 3,90 dan 3,85 . Nilai ini menunjukkan bahwa silase ransum komplit mempunyai kualitas fermentasi yang baik sekali (ditandai dengan $\mathrm{pH}<4)$. Hal ini sesuai dengan pendapat McCullough (1978) dan Macaulay (2004) yang menyatakan bahwa silase dengan $\mathrm{pH}$ 3,2-4,2 tergolong pada silase yang berkualitas baik sekali. Nilai $\mathrm{pH}$ tersebut juga mengindikasikan bahwa silase ransum komplit sudah layak disimpan.

Analisis ragam menunjukkan $\mathrm{pH}$ silase nyata $(\mathrm{P}<0,05)$ dipengaruhi oleh perlakuan jenis silase ransum komplit. Nilai $\mathrm{pH}$ terendah terlihat pada perlakuan SRKJ yaitu 3,80 , dan nilai $\mathrm{pH}$ tertinggi pada perlakuan SRKS yaitu 3,90 (Tabel 3). Perbedaan $\mathrm{pH}$ antar perlakuan ini disebabkan berbedanya bahan, komposisi kimia dan mikrobial pada masing-masing perlakuan. Hal ini sejalan dengan laporan Kizilsimsek et al. (2005) bahwa bahan baku dan tipe silo mempengaruhi kualitas silase secara fisik dan kimia. Sementara Kung dan Shaver (2001) menyatakan bahwa pH silase berhubungan dengan produksi asam laktat pada proses ensilase, $\mathrm{pH}$ yang rendah mencerminkan produksi asam laktat yang tinggi. Perlakuan SRKJ mempunyai $\mathrm{pH}$ yang lebih rendah dibanding SRKS dan SRKU. Hal ini juga didukung oleh jumlah koloni bakteri asam laktat yang lebih banyak dari pada perlakuan yang lainnya, sehingga memproduksi asam lebih tinggi. 


\section{Jumlah Koloni Bakteri Asam Laktat}

Data jumlah koloni bakteri asam laktat sebelum ensilase pada perlakuan SRKJ, SRKS dan SRKU berturut-turut adalah $6,7 \times 10^{7}, 2,7 \times 10^{6}$ dan $4,0 \times 10^{6} \mathrm{cfu} / \mathrm{g}$. Hal ini menunjukkan bahwa populasi bakteri asam laktat yang terdapat pada semua perlakuan melebihi batasan minimal ( $\left.>10^{5} \mathrm{cfu} / \mathrm{g}\right)$ untuk mendukung terjadinya proses fermentasi yang baik (McDonald et al., 1991; Buckmaster 1992). Sehingga tidak diperlukan tambahan inokulan bakteri asam laktat dari luar.

Jumlah koloni bakteri asam laktat pada masing-masing perlakuan berbeda $(\mathrm{P}<0,05)$ setelah 6 minggu ensilase. Perlakuan SRKJ memperlihatkan jumlah koloni bakteri asam laktat tertinggi $\left(9,2 \times 10^{5} \mathrm{cfu} / \mathrm{g}\right)$, diikuti perlakuan SRKS dan SRKU $\left(8,5 \times 10^{4}\right.$ dan
$8,0 \times 10^{4} \mathrm{cfu} / \mathrm{g}$ ). Proses fermentasi menyebabkan penurunan jumlah koloni bakteri asam laktat. Hal ini berhubungan dengan sifat bakteri asam laktat dan $\mathrm{pH}$ yang dihasilkan pada ensilase. Menurut Mc Donald et al. (1991) bakteri asam laktat dapat bertahan hidup mulai dari $\mathrm{pH}$ 4,0 sampai 6,8. Bahkan Pediococcus damnasus (cerevisae) dapat bertahan pada $\mathrm{pH}$ 3,5. Sementara Streptococcus umumnya bertahan pada $\mathrm{pH}$ sekitar 4,5 sampai 5,0. Sedangkan spesies Lactobacillus akan tumbuh subur pada $\mathrm{pH} 4,5$ sampai 6,4 . Tingginya populasi pada perlakuan SRKJ diperkirakan karena bakteri asam laktat pada SRKJ berbeda, dan lebih tahan terhadap $\mathrm{pH}$ rendah dibandingkan bakteri asam laktat pada perlakuan SRKS dan SRKU. Sementara itu perlakuan SRKS dan SRKU diduga mempunyai jenis bakteri asam laktat yang sama.

Tabel 2. Karakteristik fisik silase ransum komplit berbasis hasil samping jagung, sawit dan ubi kayu setelah 6 minggu ensilase.

\begin{tabular}{lccc}
\hline \multirow{2}{*}{ Peubah } & \multicolumn{3}{c}{ Perlakuan } \\
\cline { 2 - 4 } & SRKJ & SRKS & SRKU \\
\hline \multirow{2}{*}{ Warna } & campuran hijau, & campuran hijau, & campuran hijau, \\
Bau & khing dan coklat & kuning dan coklat & kuning dan coklat \\
& asam laktat & khas fermentasi & khas fermentasi \\
Keberadaan jamur $(\%)$ & 7,64 & asam laktat & asam laktat \\
\hline Kebanda & tidak ada \\
\hline
\end{tabular}

Keterangan: SRJK (silase ransum komplit berbasis hasil samping jagung), SRKS (silase ransum komplit berbasis hasil samping sawit), SRKU (silase ransum komplit berbasis hasil samping ubi kayu)

Tabel 3. Karakteristik kimia ransum komplit berbasis hasil samping jagung, sawit dan ubi kayu setelah 6 minggu ensilase.

\begin{tabular}{lccc}
\hline \multirow{2}{*}{ Peubah } & \multicolumn{3}{c}{ Perlakuan } \\
\cline { 2 - 4 } & SRKJ & SRKS & SRKU \\
\hline pH silase & $3,80^{\mathrm{c}} \pm 0,01$ & $3,90^{\mathrm{a}} \pm 0,05$ & $3,85^{\mathrm{b}} \pm 0,01$ \\
Jumlah koloni bakteri asam & $9,2 \times 10^{5 \mathrm{a}} \pm 0,46$ & $8,5 \times 10^{4 \mathrm{~b}} \pm 0,07$ & $8,0 \times 10^{4 \mathrm{bc}} \pm 0,13$ \\
laktat (cfu/g) & $4,17^{\mathrm{b}} \pm 0,24$ & $2,92^{\mathrm{c}} \pm 0,19$ & $5,68^{\mathrm{a}} \pm 0,46$ \\
Kehilangan WSC (\%BK) & $7,99 \pm 0,95$ & $7,18 \pm 0,42$ & $7,68 \pm 0,98$ \\
Kadar N-amonia (\%TN) & $7,20^{\mathrm{a}} \pm 0,45$ & $4,60^{\mathrm{bc}} \pm 1,07$ & $4,00^{\mathrm{c}} \pm 0,61$ \\
Kehilangan bahan kering (\%) & Keterangan: Superskrip yang berbeda pada baris yang sama menunjukkan pengaruh yang & berbeda nyata (P<0,05) \\
SRJK (silase ransum komplit berbasis hasil samping jagung), SRKS (silase ransum & komplit berbasis hasil \\
samping sawit), SRKU (silase ransum komplit berbasis hasil samping ubi kayu) &
\end{tabular}




\section{Kehilangan WSC (Water Soluble Carbohydrate)}

Kandungan WSC pada perlakuan SRKJ, SRKS dan SRKU sebelum ensilase adalah 8,71\% BK, 6,17\% BK dan 13,14\% BK. Hal ini mengindikasikan bahwa setiap perlakuan mempunyai kandungan WSC melebihi kebutuhan minimal (3-5\% BK) untuk mendapatkan fermentasi yang baik (McDonald et al., 1991). Data penelitian menunjukkan adanya variasi pemanfaatan WSC selama proses fermentasi pada semua perlakuan $(\mathrm{P}<0,05)$. Perlakuan SRKU memperlihatkan kehilangan WSC tertinggi yaitu $5,68 \%$ BK diikuti perlakuan SRKJ (4,17\% BK) dan SRKS (2,92\% BK) seperti terlihat pada Tabel 3. Jones et al. (2004) menyatakan bahwa proses fermentasi merupakan aktivitas biologis bakteri asam laktat mengkonversi gula-gula sederhana menjadi asam (terutama asam laktat). Komponen gula dimanfaatkan mulai dari fase awal ensilase sampai tercapainya fase stabil yang ditandai dengan dominannya bakteri asam laktat dan tidak terjadi lagi penurunan $\mathrm{pH}$. Tingginya penurunan kandungan WSC pada SRKU diduga karena mengandung komponen monosakarida lebih tinggi dibandingkan dengan kedua perlakuan lainnya. Di samping itu penurunan $\mathrm{pH}$ pada perlakuan SRKU juga lebih tinggi dibandingkan dengan perlakuan SRKJ dan SRKS (2,05 vs 1,66 dan 1,22). Sehingga bakteri asam laktat membutuhkan gula lebih banyak untuk memproduksi asam laktat.

\section{Kandungan N-amonia}

Kadar amonia ransum komplit berbasis hasil samping jagung, sawit dan ubi kayu sebelum ensilase berturut-turut $3,88 \%$ $\mathrm{TN}, 1,99 \% \mathrm{TN}$ dan $0,48 \% \mathrm{TN}$. Hal ini disebabkan terjadinya reaksi proteolisis oleh enzim tanaman pada saat pelayuan sebelum ensilase. McDonald et al. (1991) menyatakan bahwa proteolisis berlangsung sesaat setelah hijauan dipanen, dipotong dan terus berlangsung sampai beberapa jam setelah dimasukkan ke dalam silo. Reaksi ini berhenti jika kondisi anaerob dalam silo telah tercapai.

Hasil penelitian menunjukkan kadar $\mathrm{N}$-amonia setelah 6 minggu ensilase tidak dipengaruhi oleh jenis ransum komplit $(\mathrm{P}>0,05)$. Perlakuan SRKJ memperlihatkan kadar N-amonia tertinggi $(7,99 \% \mathrm{TN})$ diikuti oleh perlakuan SRKU (7,68\% TN) dan SRKS $(7,18 \%$ TN). Namun kadar $\mathrm{N}$-amonia yang didapatkan pada penelitian ini masih dalam batasan yang normal pada silase yaitu kurang 10\% (Saun dan Heinrichs 2008; Macaulay 2004; Kung dan Shaver 2001). Lebih tingginya kadar amonia perlakuan SRKJ dari pada perlakuan SRKS dan SRKU didukung oleh data penurunan kadar protein yang lebih tinggi pula $(9,98 \%$ vs $4,43 \%$ dan $5,21 \%)$.

\section{Kehilangan Bahan Kering}

Data kehilangan bahan kering menunjukkan hasil yang berbeda $(\mathrm{P}<0,05)$ pada masing-masing perlakuan silase ransum komplit. Namun perlakuan SRKS dan SRKU mengalami kehilangan bahan kering yang sama. Penurunan kandungan bahan kering tertinggi terlihat pada perlakuan SRKJ (7,20\%), diikuti oleh perlakuan SRKS $(4,60 \%)$ dan SRKU $(4,00 \%)$.

Penurunan bahan kering yang didapat pada penelitian ini masih dalam batasan normal untuk suatu produk fermentasi. McDonald et al. (1991) menyatakan bahwa persentase kehilangan bahan kering pada silase yang dikelola dengan baik berkisar antara 7-20\%. Lebih lanjut dijelaskan Davies (2007) bahwa kehilangan bahan kering tersebut terjadi saat pengisian (5\%), menjadi cairan silase $(3 \%)$, selama proses fermentasi (5\%), kerusakan karena udara (10\%) dan kehilangan di lapangan (4\%). Kehilangan ini menandakan bahwa bakteri asam laktat memanfaatkan sejumlah nutrien untuk memproduksi asam. Karbohidrat yang mudah difermentasi yaitu komponenkomponen gula non struktural seperti; glukosa, fruktosa, galaktosa, mannosa, silosa 
dan arabinosa merupakan komponen yang banyak dimanfaatkan oleh mikroorganisme selama fase fermentasi (McDonald et al., 1991).

\section{KESIMPULAN}

Silase ransum komplit berbasisis jagung, sawit dan ubi kayu mempunyai kualitas fermentasi yang baik. Hal ini ditandai dengan $\mathrm{pH}$ yang rendah $(3,8-3,9)$, kehilangan bahan kering kurang $8 \%$ dan kadar amonia kurang $10 \%$.

\section{DAFTAR PUSTAKA}

[AOAC] Association of Official Analytical Chemist. 1999. Official Methods of Analysis. Ed ke-16. Washington: AOAC International.

Buckmaster, D. 1992. Bacterial inoculants for silage. http//www.ege.psu.edu/ extension/ factsheets/i/I 111.pdf [Agustus 2008].

Conway, E.J. 1957. Microdiffusion of Analysis of Assosiation Official Analitycal Chemist: Goergia Press.

Davies, D. 2007. Improving silage quality and reducing $\mathrm{CO}_{2}$ emission. $\mathrm{http} / / \mathrm{www}$. Improving silage quality and reducing Cosub2-sub emission.htm [Agustus 2008].

Dubois, M., Gilles, K.A., Hamilton, J.K., Rebers, P.A., and Smith, F. 1956. Colorimetric method for determination of sugars and related substances. $J$ Analytical Chemistry 28(3): 350-356.

Fardiaz, S. 1992. Mikrobiologi Pangan I. Jakarta: Gramedia Pustaka Utama.

Jones, C.M., Heinrichs, A.J., Roth, G.W., and Issler, V.A. 2004. From Harvest to Feed: Understanding Silage
Management. Pensylvania: Pensylvania State University.

Kizilsimsek, M., Erol, A.,and Calislar, S. 2005. Effect of raw material and silo size on silage quality. $J$ Livestock Rasearch for Rural Development 17(3):256-263.

Kung, L. and Shaver, R. 2001. Interpretation and use of silage fermentation analysis reports. J Focus on Forage 13(3).

Macaulay, A. 2004. Evaluating silage quality. http://www1.agric.gov.ab. ca/department/ deptdocs.nsf/all/for4909. html [Feb 2008].

McCollough, M.E. 1978. Ruminant Nutrient. Rome: Food and Agricultural Organization of Limited Nation.

McDonald, P., Henderson, A.R., and Heron, S.J.E. 1991. The Biochemistry of Silage. Second Edition. Marlow: Chalcombe Publication.

[NRC] National Research Council. 1985. Nutrient Requirement of Sheep. Washington DC: National Academy Press.

Ramli, N., Ridla, M., Toharmat, T., dan Abdullah, L. 2006. Pengaruh pakan asal limbah organik terhadap produksi, kualitas dan keamanan susu serta produksi biogas sapi perah. Jakarta: Badan Penelitian dan Pengembangan Pertanian.

Saun, R.J.V. and Heinrichs, A.J. 2008. Troubleshooting silage problems: How to identify potential problem. Proceddings of the Mid-Atlantic Conference; Pennsylvania, 26-26 May 2008. Penn State's Co llage. hlm 2-10. 